\title{
Bribing to Circumvent Capture and Facilitate Participation in Social Programs: Evidence from Indian Villages
}

\author{
Raghbendra Jha \\ ANU, Canberra
}

\author{
Hari K. Nagarajan \\ NCAER, New Delhi
}

\author{
Kailash C. Pradhan \\ NCAER, New Delhi
}

\begin{abstract}
Given that the phenomenon of capture of public programs by sections the population is rampant in developing countries, households can indulge in a strategy to improve their odds of participating in public programs by bribing the suppliers of such programs. This is an important issue affecting both the supply of local public goods and the incidence of corruption. To the best of our knowledge there is no analysis of the impact of bribery on the odds of participating in a local public goods program, anywhere. Using a unique data set for rural India this paper addresses the question of whether households bribe elected officials responsible for assuring such supply to improve their access to local public goods. We find considerable evidence of such bribing. We also model the welfare effects of such bribing on groups of households as well as the impact of bribery on aggregate welfare. Several policy conclusions are advanced.
\end{abstract}

JEL Classification Codes: D31, D63, D73, O12

Keywords: Bribery, Program Capture, Welfare Effects, Rural India.

Corresponding author: Prof R. Jha, Australia South Asia Research Centre,

Arndt-Corden Dept of Economics

H.C. Coombs Building (09)

Australian National University

Canberra ACT 0200

\footnotetext{
\# This paper is part of the IDRC-NCAER research program on "Building Policy Research Capacity for Rural Governance and Growth in India" (grant number 105223). We wish to thank Hans Binswanger and Andrew Foster for comments on earlier drafts. The usual caveat applies.
} 


\section{Introduction}

Local public goods including public works have often been cited as important tools for poverty alleviation in the rural sector of developing countries (World Bank 2001). If properly designed, these have the dual advantage of reducing poverty as well as creating rural infrastructure (Scandizzo et al. 2007).

As a consequence several authors have studied the poverty alleviating impact of local public goods. However, an important caveat is that such goods may be subject to the phenomenon of local capture.

This issue of capture in the context of anti-poverty public goods type programs in India was first addressed by Lanjouw and Ravallion (1999) (henceforth LR). They compute average participation rates (for households) at the state level and for each per capita expenditure quintile and NSS region ${ }^{1}$. The average odds ratio of participation (AOP) is given by the ratio of the quintile-specific average participation rate to the overall average. The marginal oddsratio of participation (MOP) is defined as the increment to participation in that programs for any given household belonging to a specified group relative all other households. Differences between the two will reflect differences in the incidence of infra-marginal spending. If the MOP is greater than the AOP for the poorest quintile within a particular social group, then the population in the poorest quintile in this social group will benefit more than the others from a rupee increase in overall spending. In other words, there will be less capture by the non-poor from the extra spending. Jha et al. (2011) provide a broader survey of the literature on program capture particularly in the Indian context and, using large NSS data for 1993-94 and 2004-05, evaluate the incidence and temporal variation in two key social programs.

An interesting and important question in this context is the following. Can households indulge in a strategy to improve their odds of participating in a program of local public goods by bribing the suppliers of such programs? This is an important issue affecting both the supply of local public goods and the incidence of corruption. To the best of our knowledge there is no analysis of the impact of bribery on the odds of participating in a local public goods program, anywhere.

This paper addresses the question of whether households bribe elected officials to improve their access to local public goods. Our motivation is to understand whether households can

\footnotetext{
${ }^{1}$ Note that only those regions are considered that do not overlap over two states.
} 
influence the odds of accessing public goods and programs if they choose to bribe those responsible for assuring such supply.

How do we interpret the impact of bribes on aggregate welfare? We know that the system of decentralization in India is significantly flawed by its failure to transfer funds, and functionaries to the local governments. Instead, local politicians, and elected officials alike are confronted with a plethora of programs managed at higher levels because of which they have significant influence over the distribution of benefits. The complexity of and multiplicity of the rules associated with these programs create information asymmetries and the elected officials have an information advantage over both the Gram Sabha and households alike. Such a system invites elite capture by the elected officials and other socio economic groups.

In this paper we will show that households use bribes as a second best solution (in fact it is one of two "second best solutions", the other being identity based voting) to overcome the pathologies associated with the system. Although paying bribes is undesirable we show that bribes enable households to participate in many programs and achieve higher consumption. The benefits are particularly large for the ultra poor and the poor although the better off also gain from such behavior. Such a situation is not an unmixed blessing because competition between the weaker groups could lead to a significant erosion of the benefits whenever a candidate from a competing Jati wins. The net consumption gain for the poor or the ultra poor therefore cannot be identified.

The plan of this paper is as follows. Section II provides the background and data for the analysis. Section III discusses the methodology adopted in this paper. Section IV presents and discusses the results whereas section $\mathrm{V}$ concludes and provides some policy implications.

\section{Background and Data}

Post the $73^{\text {rd }}$ amendment to the Indian Constitution, political devolution has led to the emergence of Panchayats whereby a village or a group of villages is collectively referred to as a "Panchayat". Elections to the Panchayat can be either direct or indirect. Direct elections involve the election of the "Pradhan" (head of the Panchayat) as well as ward members by individuals through voting. Pradhan is typically a resident of the largest of the Panchayat villages. Ward members represent parts of the villages that form the Panchayat. Indirect elections involve first the election of ward members who then select the Pradhan. A 
Panchayat period typically lasts for five years. The Panchayat Pradhan is often vested with a range of responsibilities and powers including the identification and selection of beneficiaries for the various centrally sponsored welfare schemes, financial administration of welfare programs sponsored by state and the federal governments, conduct of Gram Sabha meetings, identification of issues related to development needs of households and groups of households as well as those that are village wide.

The nature of powers vested with the Pradhan creates conditions for information asymmetry between the Pradhan and the households, manifested particularly in issues germane to selection and identification of beneficiaries, and administration of welfare programs as well as articulation of the development needs of the village and the Panchayat to higher levels of government. $^{2}$

Why do households pay bribes? Even though in the literature (Caillaud and Tirole, 2002, Snyder and Ting, 2002, and, Alesina and Spear, 1988) it has been argued that a decentralized political apparatus is adequate to ensure commitment by elected representatives, in socially fragmented societies where groups of households defined by their Jatis may be excluded from access to public goods, or where the system of governance is synonymous with clientelism, this assumption may not be valid. In such circumstances, second best solutions like bribing and identity based voting identity mechanisms for inclusion, ensure commitment as well as access to programs. Social networks can affect not only the quality of mutual insurance but, as Munshi and Rosenzweig (2005, 2006), Banerjee and Munshi (2004) suggest, social networks can help offset the pathologies associated with imperfect designs of the system. Evidence (Binswanger, Nagarajan and Pradhan, 2011) however suggests that these mechanisms are imperfect substitutes. Hence households in response to the persistent pathologies tend to resort to bribes as an alternate second best solution.

Much of social policy in India has been designed to afford primacy to welfare of specific groups (defined either by their ethnicity or socio-economic well being). ${ }^{3}$ The Indian Constitution also recognizes and provides impetus to policy for enhancing welfare of groups based on their socio economic status in the society. The Panchayati Raj Amendment $\left(73^{\text {rd }}\right)$

\footnotetext{
${ }^{2}$ Saxena (2011) also points these out as some of the shortcomings of the designs of the current forms of decentralization and devolution.

${ }^{3}$ It has been shown elsewhere (Jha, Kang, and Nagarajan (2011)) that programs designed to affect group welfare are better targeted compared to those meant for enhancing individual welfare (such as the PDS).
} 
has enabling provisions for gender, and disadvantaged groups. ${ }^{4}$ Households therefore will derive positive externalities from membership in groups as well as social networks. The electoral process is a means for specific groups to elect a representative with a congruent identity. Voting in elections will maximize returns to specific groups and lead to significant increases in welfare of individual households that have either aligned themselves to these groups or are natural members. ${ }^{5}$ Under ideal typical conditions, decentralization and devolution is accompanied by a significant responsibility to raise local revenues. This process would allow households to enforce commitment. In the absence of such a process, and in conditions where sufficient functions, as well as functionaries have not been devolved to local governments, and instead funds are being devolved, clientelism becomes/may become the norm. Bribing and identity based voting may then become significant as methods of enforcing commitment and for accessing funds.

The system of decentralization and devolution of powers has not favored the generation of own revenue by local governments. Instead, most resources that reach the Panchayats are grants from state and national governments and reach the villages in two forms. A small proportion of funds devolved from state governments are untied grants, which are used mostly for minor repairs and maintenance and provision of public goods in a highly selective manner. ${ }^{6}$ Most programs, however, provide very specific benefits to villages, village neighborhoods or individuals in such areas as drinking water, water points, digging of private wells for irrigation, subsidies for inputs, and welfare benefits in the form of access to subsidized foods or employment schemes. Programs with individual benefits all have targeting criteria that tend to favor farmers for the inputs or members of the weaker socio-

\footnotetext{
${ }^{4}$ There is in fact much confusion in the formulation of the implementation of policies related to decentralization and devolution. This has to do with whether empowerment through decentralization must be of households or of household groups (referred to also by some as community). Saxena (2011) argues that one of the pathologies of the implementation has to do with a lack of focus on community (in fact, inability to focus) and the fact that the current design allows for individual households trying to corner benefits meant for the community. Given the nature of formation of communities (always defined by Jatis in rural India), it is only natural that such pathologies are observed. Focus on group welfare in the Indian context will always lead to this outcome for individuals within communities will act in a way to maximize community welfare and capture benefits meant for other communities.

${ }^{5}$ During elections held in number of states in northern India, the Muslims and Yadavs would vote as a bloc with Muslims identifying themselves with Yadavs (who are Hindu but ethnically and economically backward) in order to elect a member of the Yadav community.

${ }^{6}$ One of the important features of "formation" of villages in India is that streets are often formed along specific line of occupation or Jati. The degree of diversification of Jati is particularly low across villages. It is often suggested that streets are a more efficient insuring unit compared to the village taken as a whole. The current dispensation of targeting and providing both untied and tied funds to households tend to reinforce these divisions. In fact the data suggest that both provision and access to public goods and welfare programs across streets within villages is extremely skewed.
} 
economic groups. The number of such programs is large and their targeting criteria and implementation mechanisms vary widely. While the village population is often supposed to approve the targeting (through the gram sabha), the complexity of the system creates information asymmetries that favor the village and higher level officials, and give them control over targeting of benefits. This is a precondition for bribing to arise and grow.

The data used in this paper are derived from the NCAER ARIS/REDS data sets. These represent a consistent set of information on 241 villages in 17 states $^{7}$ representing rural India, collected over six rounds and encompassing the period 1969 to $2006 .^{8}$ The current round has surveyed 8659 households out of which 5885 represents the panel. ${ }^{9}$ The merged six-round panel data set is unique because it combines detailed demographic information on households, participation in welfare schemes, governance, evaluation of governance by households, composite pattern of cultivation, infrastructure, availability of public goods etc. with community data. The data cover a period of considerable change in the rural economy of India, both in terms of structure as well as the policy regime. The data allow us to trace the impact of changes in policy on the households and therefore fix these households within a policy space.

The data are in three parts viz., listing, community, and the household. In the rounds prior to 2006 the listing data was confined to identifying households for the detailed survey. However with the current (2006) round of the survey, listing represents a census of the village and forms the basis for detailed information on incomes, occupations, voting, land holdings and network formation. The community data set contains information on the structure of governance in these villages incidence, village wide shocks, composite pattern of cultivation, infrastructure, availability of public goods etc. The household survey provides detailed information on participation in governance, welfare programs, assessment of quality of welfare programs, information on networks, voting behavior, Jati, apart from usual details of cost of cultivation, household characteristics etc.

\footnotetext{
${ }^{7}$ The states include Tamil Nadu, Kerala, Karnataka, Maharashtra, Gujarat, Rajasthan, Punjab, Haryana, Uttar Pradesh, Bihar, Jharkhand, West Bengal, Orissa, Chhattisgarh, Madhya Pradesh, and, Andhra Pradesh. The state reorganization that influenced Bihar, Madhya Pradesh and Uttar Pradesh, did not affect the selection of villages that have remained intact since 1969.

${ }^{8}$ The first three rounds included Assam and Jammu and Kashmir. However, the 1982 round did not include Assam, while the 1999 round excluded Jammu and Kashmir (both incidents affected by the local law and order situation prevailing in these states at that time). The current round excludes both these states.

${ }^{9}$ The household sample has compensated for attrition through a random addition to the original sample since 1982. 10 households were randomly selected from the process of listing in each of the survey rounds. This way the sample remains representative of rural India.
} 
The data for the 1999 and 2006 rounds, encompassing two Panchayat periods in most villages, are summarized in table 1. While the average number of years of schooling has increased, we find that the size of land holdings as well as household size has declined. The latter two outcomes can be attributed to household splits within the sample. Consumption expenditures have gone up during this period and poverty has declined from 31 percent to 25 percent. However, the Gini index of consumption suggests that inequality has increased significantly and has in fact gone up from 19 to 23 percent.

Villages on an average have become better connected to urban centers, and the per capita availability of infrastructure and public goods has improved. The provision of public goods like drinking water, public taps, street lighting and sanitation has improved. The proportion of cultivated area has remained stagnant, suggesting that agricultural income growth has to come primarily from productivity growth. Welfare indicators such as number of brick houses, multi storied houses and agricultural wage rates, have improved over this time period.

Table 1 here

The profile of elected representatives across various types of Panchayats and over time periods reveals that in Panchayats where there is no political reservation for either women or Jatis, female representation at the level of elected representatives has declined marginally. However, over the same time period, where there was political reservation for women or based on Jati, the proportion of female elected representatives has increased. We note that the literacy rate of elective representatives in the Panchayats headed by women (including those villages with political reservations for women) has declined.

The representation of socially marginalized Jatis in villages with political reservation for women has shown a marginal increase. A majority of the elected representatives are landless or marginal farmers (owning and cultivating less than two acres). However, we note that in villages with political reservations for either gender or Jati, the proportion of elected representatives owning and cultivating land (i.e. 2-10 acres) has increased significantly.

The data also shows that the structure of support for elected representatives in these Panchayats is identity based (identity of the elective representatives is the most important determinant of voting). Identity-based voting on the basis of Jatis is much more important than that based on religion. In addition, elected representatives get significant support from 
wealthy persons. However, the structure of support to the elected representatives from outside the Panchayat does not mirror that of internal support. In particular, we notice that a significant source of outside support is from political parties. All measures of political support from the outside, from Jati, religion, or political parties have increased somewhat over time.

Table 2 here

What does the data say about the various dimensions of bribes? In table 3 we show that across the two Panchayat periods (past 10 years), the proportion of households that have been adversely affected by inadequate provision, quality, and governance related to community wide factors such as water, health care, roads, schooling (education), street lighting and sanitation has been persistently high and increasing (though the magnitude of increase is not very large). Similarly, the quality of household specific issues related to local governance such as implementation of public works programs, access to schools, working of the local health centers are continuing to adversely impact a large percentage of households. In addition to this incidence of malpractices associated with functioning of the public distribution system, mid day meals program beneficiary selection etc have all increased. What is most revealing from this table is the proportion of such adversely affected households that have to pay bribes to rectify (or at least attempt to rectify) these maladies. An average of $70 \%$ of all affected households paid bribes and this increased to $72 \%$ in the current Panchayat period.

Table 3 here

Another noteworthy factor is the increasing complexity of the procedures. Devolution was supposed to empower households in villages by simplifying processes and procedures. We instead find that the number of functionaries approached by an average household has more than doubled. Table 4 also points out that across all classes of households; the proportion of households that paid bribes to access functionaries and benefits has increased along with the number of functionaries contacted and approached for benefits and problem solving.

Table 4 here 
In table 5 the most revealing statistic is the per capita magnitude of bribes relative to the various types of welfare expenditures. We find that in 2006 nearly $19 \%$ of all benefits received from welfare programs went back as bribes. This figure was $15 \%$ in the previous Panchayat period. Are these bribes being capitalized? If so then rising bribes may not be a problem. However we find that the proportion of households that repeatedly pay bribes is very high and is increasing over time. Hence, bribes constitute a significant, directly unproductive, outflow of resources out of the village economy.

Table 5 here

\section{Methodology}

Payment of bribes facilitates participation in welfare programs by improving the marginal odds of participation (MOP) relative to the average odds of participation (AOP). In the context of our analysis we establish this, first, by showing that MOP for groups of households that paid bribes are greater than that for groups that attempted to participate but did not pay bribe.

Before estimating MOP and AOP, it is necessary to estimate the predicted participation of households in welfare programs. We estimate the predicted participation by households with and without payment of bribes. However, we need to recognize the fact that predicted participation can be estimated directly when bribes are not paid but this cannot be estimated directly when bribes are paid because payment of bribes is endogenous to participation in welfare programs. We recognize this mutual endogeneity and use three stage least square estimation procedures to estimate the predicted participation with payment of bribes. Our modus operandi is as follows.

\section{i) Estimation of Participation in Welfare Program without payment of bribes}

We estimate the participation equation in welfare program without bribe payment as: $P_{i}=\tau_{0}+\kappa_{n} K_{i}+\xi_{i}$

where $P_{i}$ is the change in the number of welfare programs participated in by ith household, $K_{i}$ is a vector of exogenous variables including Dummy for poor (2006), Dummy for poor (1999), Gender of the household (Male=1, Female=0), Dummy for SC, Dummy for ST, 
Dummy for $\mathrm{OBC}$, and program growth. $\tau_{0}$ is a constant, $\kappa_{n}$ is the estimated $n$th parameter, and $\xi_{i}$ is the random error term.

\section{ii) Estimation of Participation in Welfare Program with payment of bribes}

We estimated the household's participation in welfare with payment of bribes by using three stage least square estimation procedures. We posit that changes in per capita consumption, changes in payment of bribes, and program participation are jointly determined. A three stage estimation strategy has been adopted where for a linear system of $\mathrm{M}$ equations which are jointly dependent on exogenous and predetermined variables.

$y_{i}=Y_{i} \gamma_{i}+X_{i} \beta_{i}+u_{i} \quad i=1,2 \ldots \mathrm{M}$.

$y_{i}=Z_{i} \delta_{i}+u_{i}, \quad Z_{i}=\left(Y_{i} X_{i}\right), \quad \delta_{i}=\left(\begin{array}{l}Z_{i} \\ \delta_{i}\end{array}\right)$

where the T-vector $y_{i}$ contains the observations on the ith dependent variable to be explained by the $i$ th structural equation; $Y_{i}\left(T \times m_{i}, m_{i}<M\right)$ less than or equal to $\mathrm{M}$ where this contains observations on jointly dependent variables included as explanatory variables in the ith equation, $X_{i}\left(T \times l_{i}, l_{i}<A\right)$ less than or equal to A where this is the matrix of predetermined variables included in the ith equation, $\gamma_{i}$ and $\beta_{i}$ are corresponding vectors of unknown parameters, $u_{i}$ is a T-vector of disturbances satisfying

$E\left(u_{i}\right)=0$

$E\left(u_{i} u_{i}^{\prime}\right)=\sigma_{i j} I_{T}, \quad i, j=1,2 \ldots \mathrm{M}$.

The distribution of the disturbances is supposed to be independent of the predetermined variables in the system, the reduced form is assumed to exist and the equations are either just identified or over identified (Kapteyn and Fiebig, 1981).

\section{iii) Estimating Change in Household Wealth}

We estimate wealth equation and predict change in household's wealth. In a panel data framework, changes in household welfare can be affected by household splits. Predicted household splits can be adequately proxied by predicted change in wealth (Foster and Rosenzweig, 2001). We estimate and predict the change in wealth as follows.

$$
\Delta W_{i t}=k_{0}+\phi_{j} S_{j i t}+v_{i t}
$$


where, $i$ indexes household, and $t$ is time, $\Delta W_{i t}$ is the change in the household's wealth, $S_{j i t}$ is the vector of variables that predicts changes in the households wealth it includes age of head of the household, change in variance and mean of education of members of household, number of children whose age is less than 15 years, inherited wealth at the beginning of the period (1999), dummies for whether father is co-resident for beginning and at end of the periods (1999 and 2006), dummies for whether both brothers and sisters are co-resident at the beginning and end of the periods (1999 and 2006), $j$ indexes these variables and $v_{i t}$ is the error term.

\section{iv) Estimating Changes in Per Capita Consumption}

Change in household's welfare is measured by changes in its per capita consumption which is measured as follow.

$$
\Delta C_{i t}=\alpha_{0}+\alpha_{1} \widehat{W}_{i t}+\beta_{1} R C_{1 i t}+\beta_{2} R C_{2 i t}+\lambda_{k} X_{k i t}+\mu_{i t}
$$

Where, $\triangle P C_{i t}$ is the change of per capita consumption expenditure, $\widehat{W}$ is the predicted wealth, $R C_{1 i t}$ is the regime change in the village associated with gender, $R C_{2 i t}$ is the regime change associated with Jati. $X_{i j t}$ is a vector of exogenous variables that includes the public expenditures on agricultural programs, public expenditures on welfare programs, village untied grants, village level shocks, household level shocks, education of head of the household and household size. $u_{i t}$ is the error term.

The unique identifiers for the consumption function are predicted changes in household wealth and regime changes. Change in wealth is a consequence of household splits and will adequately explain changes in per capita consumption at the household level. The village level regime changes will influence consumption since they affect quality of governance, service delivery, allocations across welfare programs, beneficiary selection etc.

\section{v) Estimating Payment of Bribes}

A number of factors affect the change in the magnitude of payment of bribes. We construct a bribe index to measure the intensity of payment of bribes. The bribe index (which is village level index) is measured as follows.

$$
B I_{i}=\left(D f_{i} \times D b_{i}\right) \times\left(\frac{A B_{i}}{T B_{i}}\right)
$$


where $B I_{i}$ is the bribe index of a given household $i$ and $D f_{i}$ is a dummy variable taking value 1 if household $i$ approaches Pradhan or Ward member for a range of issues as described in table 3. Such issues relate to both community and the household. Otherwise the dummy variable is $0 ; D b_{i}$ is a dummy variable taking value 1 if a household pays bribe to Pradhan or Ward members, otherwise it is $0, A B_{i}$ is the amount of bribe paid to the Pradhan or Ward members and $T B_{i}$ is the total amount of bribe paid to any of the functionaries. The summation of household level bribe indices gives us a village bribes index which ranges from 0 to 1 . The closer is the index to 1 the greater is the intensity of payment of bribes. The bribe index uniquely identifies the changes in payment of bribes. A weaker identifier than the bribe index is the numerical size of the household's own Jati within the village. Change in payment of bribes is estimated as follows:

$$
\Delta B_{i t}=a_{0}+b_{1} B I_{i t}+c_{l} C_{l i t}+\varepsilon_{i t}
$$

where $\Delta B_{i t}$ is change in payment of bribes by the households, $B I_{i t}$ is the bribe index, $C_{l i t}$ is the vector of all other explanatory variables such as proportion of members of household participating in welfare programs, proportion of own Jati who voted based on identity, proportion of majority Jati who voted based on identity, numerical size of own Jati and majority Jati.

\section{vi) Estimating Participation in Welfare Programs}

Change in number of welfare programs participated in is estimated in the following manner.

$$
\Delta W P_{i t}=\pi_{0}+\varpi_{1} B_{i t}+\gamma_{m} D_{m i t}+\vartheta_{i t}
$$

Where $\Delta W P_{i t}$ is change in the number of welfare programs participated by household $i, B_{i t}$ is change of bribe payment by the household, $D_{m i t}$ is vector of variables which includes growth in number of village level welfare programs, changes in payment of bribes with interaction terms such as poor, growth in agricultural programs, growth in public goods, growth in untied resources and growth in general welfare programs. The unique identifier for this equation is change in number of welfare programs in the village.

What do bribes achieve? We wish to examine both the impact of bribes on consumption and the overall effect on specific groups of households. We use the results obtained from the 3SLS estimation and model the impact of payment of bribe on MOP and AOP as follows. 


\section{vii) Impact of payment of Bribes on Program Capture}

We establish the relationship between AOP and MOP for households belonging to different consumption classes, based on whether the household paid bribes for gaining participation in welfare programs. The average participation rate for any given class of consumption per person is the proportion of households in that class of consumption per person which participates in the program. The AOP is given by the ratio of the particular consumption class-specific average participation rate to the overall average. The MOP is defined as the increment to participation in that program. If the MOP for a group is higher than the AOP then the likelihood of participation in the welfare program for any given households of that group will be higher. The benefits of welfare programs to that group will be allocated more to households of that group. We estimate the following equation.

$$
A P_{i t}=\varphi_{0}+\varphi_{1} \hat{T P}_{i t}+\varphi_{2} w_{i t}+\psi_{i t}
$$

where $A P_{i t}$ is the average predicted participation rate for a given consumption class of a household who paid bribe or did not pay bribe, $\hat{T P}_{i t}$ is the overall participation rate across all consumption classes which is instrumented by the "leave-out mean" for a given consumption class (i.e. $L O M P_{i t}$ ) and the village wage rate, i.e., $w_{i t}$, and $\psi_{i t}$ is the random error term.

If, for a regression for a particular consumption class, the coefficient $\varphi_{1}$ is positive significant and greater (less) than 1 then the capture of the program by that consumption class has increased (decreased). If the coefficient is not significant then there has been no significant change in the incidence of capture by households in the consumption class under consideration. Households within any given consumption class that pays bribes will increase the odds of participation in the welfare program.

\section{Results}

The maintained hypothesis, empirical formulation and the data allow us to use unique identifiers such as a) change in wealth b) bribe intensity index and, c) change in number of welfare programs in the villages to make robust and consistent predictions. Since the design of decentralization and devolution allows the elected representatives an undue leeway in allocation of funds and programs across households, it is important to examine whether certain forms of regime changes can have significant impacts on consumption growth. The intensity of bribes reflects both the magnitude and frequency of bribes and, in a sense, an 
index of village governance. We examine the role of such identifiers on program participation, bribes, and, ultimately on welfare (consumption growth). We now discuss our results.

The Hansen-Sargan tests show that the system is not over identified. We are able to conclude that the joint estimation provides a more efficient estimate of consumption growth as well as identifying significant pathologies that inhibit drivers of consumption growth.

Regime changes at the village level will affect per capita consumption growth. ${ }^{10}$ Since the structure of devolution is such that the powers of incurring expenditures as well as other decisions related to household welfare are now vested with, or heavily influenced by, elected representatives (particularly with the Pradhan), any given regime now has powers to discriminate among beneficiaries. Therefore it is important to condition consumption on the type of the elected regime. It has significant implications for policies germane to reservations (gender or caste).

Four types of regime changes are identified. If the Jati of the elected representative is congruent to a household's own Jati then it is more likely to increase the per capita consumption growth of this household. Joint estimation of consumption with payment of bribes and program participation yield several revealing results related to the role of regime changes. If there is an "adverse" regime change (i.e., the Pradhan in the current period is of a different Jati compared to that of the household) then consumption growth declines by as much as $2 \%$, and this is not symmetric to a favorable change in the regime where the Jati of the Pradhan and the household become congruent (is the change is such that the Jati of the Pradhan is congruent of the household the impact is 6\%). A gender based regime change (female to male) adversely affects consumption growth by $8 \%$. In the context of this paper, one can conjecture at this point that a female Pradhan is less likely (on an average) to discriminate during the process of governance.

We find that the impacts of wealth and changes to household size on consumption are significant. The changes in household size (in particular increases) will have a negative effect on consumption if, in particular, participation in welfare program is limited by problems of access, and other pathologies. It is also apparent that joint estimation brings out the

\footnotetext{
${ }^{10}$ Since household splits will have significant effects on changes in the household's welfare we identify the consumption function by changes in wealth which, itself, is predicted by household splits. Thus, estimating change in consumption function without controlling for predicted change in wealth will lead to improper identification.(Both the results and the methodology are consistent with Foster and Rosenzweig (2004))
} 
importance of untied village resources to household consumption in an efficient manner. There is a $9 \%$ increase in consumption growth caused by increases to untied grants. Such untied funds are also a significant source of insurance for households compared to comparable access to other types of programs. There is $13 \%$ decline in consumption growth in response to adverse household level shocks. Untied village level grants provide a significant source of insurance (the decline in consumption growth is arrested by as much as $10 \%$ ).

An increase in the intensity of bribes significantly increases the magnitude and frequency of bribes for households. This result points to a systemic defect where the complexities of processes and procedures have increased and there is a general increase in the level of information asymmetry between the households and the elected officials managing the system. We also notice that the impact of members of own Jati is insignificant. In fact it could even lead to a reduction in bribes. However if the majority Jati (that is households whose Jatis are non congruent) pay bribes this is perceived as a threat to household welfare due to expected reductions in program participation and, as a consequence, significantly increases bribes (by 53\%). This is important evidence of the existence of competition between Jatis for the economic pie which, itself, is being provided without clarifying the rules of access.

The number of programs in the village significantly identifies the equation for program participation. We find that the poor pay bribes and increasingly do so. What is interesting to note joint effect of growth in the payment of bribes and the growth in various types of welfare programs; we find that this has a significant impact on program participation by households. The evidence from table 5 already points out to a per capita increase in bribes and various welfare programs. The regression results confirm this and show that the joint effects are as much as $8 \%$ to $12 \%$. Table 6 reports results on change in participation following the payment of bribes.

Table 6 here

Are bribes therefore a bad? The answer is not very clear cut give their welfare effects for the poor and the ultra poor. Some of the welfare effects are discussed in tables 7 and 8 . The results pertaining to program capture are particularly revealing. What they clearly indicate is that bribes increase the odds of participation of the bribe paying household relative to the rest 
of the households in its own group. This is suggestive of the extent of heterogeneity of groups in terms of the propensity to capture as well as the pitfalls of designing programs that tend to affect household groups. What is significant from these results is that bribes tend to expand across groups, i.e., bribes are defensive mechanism adopted by an individual household belonging to a specific group. Such measures will be adopted by households across economic groups in order to prevent program capture. Table 7 clearly proves this. The marginal odds of participation becomes significantly greater than the AOP after payment of bribes for ultra poor, poor and even for non poor households. Bribes become an economy wide phenomenon. Table 8 indicates that the rate of growth of consumption is the largest for the ultra poor. It increases by as much as 5 times. Even for the poor this increase is nearly $200 \%$. Bribes enhance program participation to such an extent for these groups that their respective consumption growth is significantly positive. Therefore are bribes bad? The answer on two counts is yes. Since bribes represent a net outflow from the local economy the village welfare is not maximized though it may lead to certain households or even groups of households to maximize their respective welfares. Secondly, competition between the weaker groups could lead to a significant erosion of the benefits whenever a candidate from a competing Jati wins. The net consumption gain for the poor therefore cannot be identified from this paper.

Tables 7 and 8 here.

\section{Conclusions}

The following conclusions can be offered.

1. Bribes are an inevitable outcome of the information asymmetries arising out of the pathologies associated with the system. They represent an attempt by households to increase their chances of participating in welfare programs.

2. Bribes actually increase individual and even group welfare. However there is no evidence that they may increase aggregate welfare as there is evidence that bribes represent a net outflow of resources from villages.

3. Program capture is/can be minimized or even avoided by participants who pay bribes. This in itself is not a positive outcome as it could lead to capture of programs by bribe-paying 
individuals. This ensures that bribes become an economy wide phenomenon since individuals and households compete to prevent or engage in capture.

4. Policy to counter bribes in decentralized environments is fairly obvious. The rules of access must be made clearer in addition to improving the mechanisms of targeting the various welfare programs.

\section{References}

Alesina, Alberto and, Stephen E. Spear (1988) "An Overlapping Generations Model of Electoral Competition", Journal of Public Economics 37: 359-79.

Banerjee, Abhijit and, Kaivan Munshi (2004) "How Efficiently is Capital Allocated? Evidence from the knitted garment industry in Tirupur", Review of Economic Studies 71(1):19-42.

Caillaud, Bernard and Jean Tirole (2002) "Parties as Political Intermediaries", Quarterly Journal of Economics 117(4): 1453-89.

Foster A. and M. Rosenzweig (2001) "Imperfect Commitment, Altruism, and the Family: Evidence from transfer behavior in low-income rural areas", The Review of Economics and Statistics, 83(3), 389-407.

Foster, A. and M. Rosenzweig (2004) "Agricultural Productivity, Growth, Rural Economic Diversity and Economic Reforms: India, 1970-2000", Economic Development and Cultural Change, 52(3), pp. 509-42.

Jha, R., S. Bhattacharyya and R. Gaiha (2011) "Temporal Variation of Capture of Anti-Poverty Programs: rural public works and food for work programs in rural India", International Review of Applied Economic, 25(3), 349-362.

Kapteyn, A. and, D. Fiebig (1981) "When are Two Stage Least Squares and Three Stage Least Squares Identical?” Economics Letters, 8(1), pp. 53-57

Lanjouw, P. and M. Ravallion (1999) "Benefit Incidence and the Timing of Program Capture", World Bank Economic Review, 13(2), 257-73.

Munshi, Kaivan and Mark Rosenzweig (2005) "Why is Mobility in India so Low? Social insurance, inequality and growth", BREAD Working Paper No. 092.

Munshi, Kaivan and Mark Rosenzweig (2006) "Traditional Institutions Meet the Modern World: Caste, gender and schooling choice in a globalizing economy", American Economic Review, 96(4):1225-52.

Scandizzo, P.L., R. Gaiha and K. Imai (2007) "Does the Employment Guarantee Scheme Stabilize Household Incomes in Rural India?", Applied Economics Letters, November, pp. 1-5.

Snyder, Jr., James M. and Michael M. Ting 2002 “An Informational Rationale for Political Parties”, American Journal of Political Science 46(1): 90-110.

World Bank (2001) World Development Report 2000, New York: Oxford University Press. 
Table 1: Sample, Village and Household Characteristics: 1999-200611

\begin{tabular}{|c|c|c|}
\hline Variables & 2006 & 1999 \\
\hline \multicolumn{3}{|l|}{ Sample Characteristics } \\
\hline Number of states & 17 & 17 \\
\hline Number of Districts & 104 & 104 \\
\hline Number of Blocks & 163 & 163 \\
\hline Number of villages & 241 & 241 \\
\hline Number of households & 5,885 & 5,885 \\
\hline Average number households in all villages & 700.50 & 622.9 \\
\hline \multicolumn{3}{|l|}{ Village Characteristics } \\
\hline \multicolumn{3}{|l|}{ Indicators of Infrastructure (km.) } \\
\hline Average distance from Bus Stand (km.) & 2.64 & 3.23 \\
\hline Average distance from School (km.) & 1.95 & 1.64 \\
\hline Average distance from Pucca road (km.) & 1.11 & 2.48 \\
\hline Average distance from Post office $(\mathrm{km})$. & 1.61 & 1.79 \\
\hline Average distance from Railway station (km.) & 25.14 & 27.02 \\
\hline \multicolumn{3}{|l|}{ Welfare indicators } \\
\hline Average number of Public taps in a village & 3.44 & 3.10 \\
\hline Average number of Drinking wells in a village & 2.51 & 2.55 \\
\hline Average number of Street lights in a village & 3.60 & 3.03 \\
\hline Average number of Public toilets in a village & 0.67 & 0.39 \\
\hline \multicolumn{3}{|l|}{ Development Indicators } \\
\hline Average number of households with brick houses & 277.55 & 240.97 \\
\hline Average number of households with huts & 44.92 & 56.55 \\
\hline Average number of households with mud houses & 126.41 & 129.13 \\
\hline Average number of households with multi storey houses & 52.36 & 34.36 \\
\hline Proportion of houses with electricity connection & 0.49 & 0.43 \\
\hline Proportion of cultivated area irrigated & 0.49 & 0.46 \\
\hline Proportion of Area irrigated by govt. Canal & 0.17 & 0.16 \\
\hline Village Harvest Wage (Rs.) & 52.24 & 49.25 \\
\hline Land Gini & 0.55 & 0.56 \\
\hline Consumption Gini & 0.23 & 0.19 \\
\hline \multicolumn{3}{|l|}{ Household Characteristics } \\
\hline Household Size & 5.24 & 6.23 \\
\hline Age of head & 51.16 & 49.42 \\
\hline No. of Earners & 1.86 & 1.74 \\
\hline Year of Schooling & 5.11 & 4.46 \\
\hline Land owned & 4.61 & 5.25 \\
\hline Irrigated land (in acres) & 2.72 & 2.85 \\
\hline Un irrigated land (in acres) & 1.88 & 2.39 \\
\hline Per capita consumption (Rs) & 6568.28 & 5857.37 \\
\hline Poverty (Head Count) & 24.98 & 30.60 \\
\hline Ultra-Poor: ${ }_{p c e}<1 / 2(p l)$ & 3.41 & 1.5 \\
\hline Poor: $1 / 2(p l)<p c e<p l$ & 21.57 & 29.1 \\
\hline Non-Poor: $p l<p c e<2(p l)$ & 52.45 & 50.9 \\
\hline Affluent: $p c e>2(p l)$ & 22.57 & 18.5 \\
\hline
\end{tabular}

\footnotetext{
${ }^{11}$ Source: Listing sheet, village and Household Schedules for 1999 and 2006 surveys
} 
Table 2: Profile of Elected Representatives in Current and Previous Panchayats ${ }^{12}$

\begin{tabular}{|c|c|c|c|c|c|c|}
\hline \multirow[b]{2}{*}{$\begin{array}{l}\text { Elected local representative's } \\
\text { Characteristics }\end{array}$} & \multicolumn{2}{|c|}{ Unreserved } & \multicolumn{2}{|c|}{ Reserved for Women } & \multicolumn{2}{|c|}{ Caste based reservation } \\
\hline & $\begin{array}{c}\text { Current } \\
\text { Panchayat }\end{array}$ & $\begin{array}{l}\text { Previous } \\
\text { Panchayat }\end{array}$ & $\begin{array}{c}\text { Current } \\
\text { Panchayat }\end{array}$ & $\begin{array}{l}\text { Previous } \\
\text { Panchayat }\end{array}$ & $\begin{array}{c}\text { Current } \\
\text { Panchayat }\end{array}$ & $\begin{array}{l}\text { Previous } \\
\text { Panchayat }\end{array}$ \\
\hline \multicolumn{7}{|l|}{ Sex } \\
\hline Male & 88.34 & 87.67 & - & - & 81.82 & 88.05 \\
\hline Female & 11.66 & 12.33 & - & - & 18.18 & 11.95 \\
\hline \multicolumn{7}{|l|}{ Education } \\
\hline Illiterate & 9.68 & 7.37 & 38.41 & 35.00 & 17.22 & 20.63 \\
\hline Primary School & 33.58 & 39.17 & 41.59 & 37.78 & 45.85 & 42.50 \\
\hline Secondary School & 37.83 & 41.01 & 16.81 & 20.00 & 29.25 & 25.63 \\
\hline Higher & 18.91 & 12.44 & 3.19 & 7.22 & 7.68 & 10.63 \\
\hline \multicolumn{7}{|l|}{ Religion } \\
\hline Hindu & 81.82 & 80.18 & 98.34 & 89.56 & 93.45 & 95.00 \\
\hline Muslim & 7.33 & 7.37 & 0.41 & 5.49 & 5.66 & 1.25 \\
\hline Other(Sikh + Christian + Jain) & 10.85 & 12.45 & 1.25 & 4.95 & 0.89 & 3.75 \\
\hline \multicolumn{7}{|l|}{ Caste } \\
\hline SC/ST & 11.66 & 11.11 & 33.03 & 32.60 & - & - \\
\hline OBC & 37.07 & 43.06 & 46.68 & 46.41 & - & - \\
\hline $\mathrm{OC}$ & 51.27 & 45.83 & 20.29 & 20.99 & - & - \\
\hline \multicolumn{7}{|c|}{ Within the village support received from } \\
\hline Caste & 84.02 & 82.92 & 88.57 & 85.16 & 86.25 & 82.24 \\
\hline Religion & 33.33 & 25.23 & 16.38 & 20.88 & 30.04 & 28.13 \\
\hline Wealthy person & 52.05 & 43.69 & 38.86 & 42.31 & 39.04 & 43.75 \\
\hline Identity (either caste or religion) & 89.23 & 84.93 & 92.57 & 87.36 & 88.75 & 87.06 \\
\hline \multicolumn{7}{|c|}{ Outside support was received from } \\
\hline Caste & 31.05 & 28.00 & 35.16 & 30.48 & 33.13 & 32.02 \\
\hline Religion & 10.50 & 9.38 & 5.49 & 6.67 & 14.04 & 10.63 \\
\hline Political party & 51.14 & 44.77 & 48.35 & 36.76 & 45.63 & 35.09 \\
\hline Identity (either caste or religion) & 34.70 & 30.77 & 37.36 & 33.14 & 35.63 & 33.33 \\
\hline \multicolumn{7}{|l|}{ Land owned } \\
\hline Landless & 38.36 & 32.07 & 30.27 & 37.36 & 32.44 & 29.38 \\
\hline $0-2$ & 36.07 & 47.52 & 49.56 & 40.11 & 42.36 & 48.13 \\
\hline $2-4$ & 15.98 & 9.04 & 9.03 & 11.54 & 8.26 & 8.75 \\
\hline $4-10$ & 7.31 & 8.75 & 7.96 & 7.69 & 13.64 & 11.88 \\
\hline$>10$ & 2.28 & 2.62 & 3.19 & 3.30 & 3.31 & 1.88 \\
\hline
\end{tabular}

\footnotetext{
${ }^{12}$ Source: Village Schedule
} 
Table 3: Factors Affecting Payment of Bribes

\begin{tabular}{|c|c|c|c|c|c|c|}
\hline & \multicolumn{3}{|c|}{ Current Panchayat Period } & \multicolumn{3}{|c|}{ Previous Panchayat Period } \\
\hline Variables & $\begin{array}{c}\text { Proportion of } \\
\text { households } \\
\text { affected }\end{array}$ & $\begin{array}{c}\text { Proportion of } \\
\text { households that } \\
\text { paid bribe }\end{array}$ & $\begin{array}{l}\text { Average number } \\
\text { of functionaries } \\
\text { approached }\end{array}$ & $\begin{array}{c}\text { Proportion of } \\
\text { households } \\
\text { affected }\end{array}$ & $\begin{array}{c}\text { Proportion of } \\
\text { households } \\
\text { that paid bribe }\end{array}$ & $\begin{array}{l}\text { Average number } \\
\text { of functionaries } \\
\text { approached }\end{array}$ \\
\hline \multicolumn{7}{|c|}{ Issues Pertaining to the community } \\
\hline Water & 0.797 & 0.82 & 2.32 & 0.780 & 0.80 & 1.56 \\
\hline Health & 0.559 & 0.609 & 3 & 0.533 & 0.586 & 1.64 \\
\hline Road & 0.758 & 0.807 & 2.23 & 0.741 & 0.766 & 1.41 \\
\hline Education & 0.376 & 0.741 & 2.15 & 0.363 & 0.620 & 1.47 \\
\hline Street light & 0.772 & 0.667 & 2.12 & 0.638 & 0.638 & 1.42 \\
\hline Sanitation & 0.753 & 0.680 & 2.15 & 0.632 & 0.634 & 1.32 \\
\hline Other & 0.489 & 0.518 & 2.14 & 0.475 & 0.488 & 1.37 \\
\hline \multicolumn{7}{|c|}{ Issues that affect you or your family } \\
\hline $\begin{array}{l}\text { Public work } \\
\text { Program }\end{array}$ & 0.821 & 0.895 & 2.242 & 0.685 & 0.781 & 1.54 \\
\hline Education & 0.182 & 0.213 & 2.261 & 0.163 & 0.190 & 1.42 \\
\hline Health & 0.745 & 0.784 & 3 & 0.143 & 0.655 & 1.55 \\
\hline Other & 0.200 & 0.234 & 2.15 & 0.223 & 0.234 & 1.348 \\
\hline \multicolumn{7}{|c|}{ Incidence of mal practices } \\
\hline $\begin{array}{l}\text { Beneficiary } \\
\text { selection }\end{array}$ & 0.680 & 0.824 & 2.09 & 0.662 & 0.695 & 1.43 \\
\hline $\begin{array}{l}\text { Mid day meal } \\
\text { scheme }\end{array}$ & 0.414 & 0.850 & 3 & 0.375 & 0.588 & 1.81 \\
\hline $\begin{array}{l}\text { Functioning of } \\
\text { ration shop }\end{array}$ & 0.779 & 0.898 & 2.17 & 0.680 & 0.789 & 1.28 \\
\hline $\begin{array}{l}\text { Ration card } \\
\text { distribution }\end{array}$ & 0.640 & 0.797 & 2.22 & 0.625 & 0.687 & 1.47 \\
\hline Observations & 5854 & 3501 & - & 5854 & 3005 & - \\
\hline
\end{tabular}

Table 4: Payment of Bribes and Access to Functionaries

\begin{tabular}{|l|c|c|c|c|}
\hline Variables & \multicolumn{2}{|c|}{ Current Panchayat Period } & \multicolumn{2}{c|}{ Previous Panchayat Period } \\
\hline Consumption classes & $\begin{array}{c}\text { Proportion of } \\
\text { households } \\
\text { that paid bribes }\end{array}$ & $\begin{array}{c}\text { Average number } \\
\text { of functionaries } \\
\text { approached }\end{array}$ & $\begin{array}{c}\text { Proportion of } \\
\text { households } \\
\text { that paid bribes }\end{array}$ & $\begin{array}{c}\text { Average number } \\
\text { of functionaries } \\
\text { approached }\end{array}$ \\
\hline Poorest (Bottom one-third) & 0.737 & 2 & 0.698 & 1.558 \\
\hline Medium (Middle one-third) & 0.692 & 2.317 & 0.651 & 1.465 \\
\hline High (Upper one-third) & 0.729 & 2.174 & 0.715 & 1.315 \\
\hline Observations & 3501 & - & 3005 & - \\
\hline
\end{tabular}


Table 5: Percentage of Participation and Bribe

\begin{tabular}{|l|c|c|}
\hline \multicolumn{3}{|c|}{ Participation in welfare program and bribe } \\
\hline Variables & $\begin{array}{c}\text { Current } \\
\text { Panchayat } \\
\text { Period }\end{array}$ & $\begin{array}{c}\text { Previous } \\
\text { Panchayat } \\
\text { Period }\end{array}$ \\
\hline Total Households & 5885 & 5885 \\
\hline Number of villages in the sample & 241 & 241 \\
\hline Bribe ${ }^{13}$ & \multicolumn{2}{l|}{} \\
\hline Not paid bribe & 48.11 & 58.47 \\
\hline Paid bribe & 51.89 & 41.53 \\
\hline Per household paid bribe (Rs.) & 76.738 & 56.67 \\
\hline Direct access to functionary14 & 97.91 & 97.73 \\
\hline Links to functionary15 & 2.09 & 2.27 \\
\hline Participation ${ }^{16}$ & \multicolumn{2}{|l|}{} \\
\hline Average number of program participation & 1.92 & 1.49 \\
\hline Not participated in welfare program & 4.45 & 5.91 \\
\hline Participated in welfare program & 95.55 & 94.09 \\
\hline Per capita expenditure in agricultural program (Rs.) & 71.92 & 146.01 \\
\hline Per capita expenditure in public goods (Rs.) & 75.32 & 75.67 \\
\hline Per capita expenditure in untied resources (Rs.) & 144.26 & 92.87 \\
\hline Per capita expenditure in public welfare programs (Rs.) & 117.05 & 73.38 \\
\hline Bribe \& Participation & & \\
\hline Participated in welfare program and paid Bribe ${ }^{17}$ & 49.38 & 38.32 \\
\hline Participated in welfare program and not paid bribe & 46.17 & 55.77 \\
\hline Not Participated in welfare program and paid Bribe & 2.28 & 3.01 \\
\hline Not Participated in welfare program and not paid Bribe & 2.17 & 2.90 \\
\hline First time participants and paid bribe & 4.34 & 7.27 \\
\hline Repeated time participants and paid bribe & 32.03 & 16.92 \\
\hline
\end{tabular}

\footnotetext{
${ }^{13}$ If a household paid a bribe to participate in any one of the welfare programs then it is counted as 1 else 0.

${ }^{14}$ If the household paid bribe to the functionary responsible for the administrator of the program then it is counted as 1 else 0 .

${ }^{15}$ If the household paid bribe to some one other than the responsible functionary due to perceived links of the recipient of the bribe to the functionary then it is counted as 1 else 0 .

${ }^{16}$ If the household participated in any one of the welfare programs then it is counted as 1 else 0.

${ }^{17}$ If household participated in any one of the welfare programs and also paid bribe it is counted as 1 else 0 .
} 
Table 6: Change in Participation in Welfare Program with Payments of Bribes

\begin{tabular}{|c|c|c|}
\hline Variable & Coefficient & t-ratio \\
\hline \multicolumn{3}{|l|}{ Change in per capita consumption } \\
\hline Predicted change in wealth & $0.052^{* *}$ & 6.26 \\
\hline Change in public expenditures on agricultural program $(A)$ & $0.007 * \star \star$ & 3.85 \\
\hline Change in public expenditures on public goods (B) & 0.001 & 0.42 \\
\hline Change in village untied expenses ( $\mathrm{C}$ ) & $0.092^{\star \star \star}$ & 2.33 \\
\hline Change in public expenditures on welfare program & $0.013 * \star$ & 2.02 \\
\hline Regime change1 (change in female Pradhan to male Pradhan) & $-0.084^{\star \star *}$ & -5.12 \\
\hline Regime change2 (change in male Pradhan to female Pradhan) & 0.019 & 1.21 \\
\hline Regime change3 ( change in own Jati to other Jati) & $-0.020 * * *$ & -2.72 \\
\hline Regime change4 ( change in other Jati to own Jati) & $0.062^{\star \star *}$ & 3.92 \\
\hline Number of village level shocks between 1999 and 2006 & 0.001 & 0.27 \\
\hline Change in number of household level shocks & $-0.138 * *$ & -2.33 \\
\hline Change in number of household level shocks* $(A)$ & $0.014^{* *}$ & 1.94 \\
\hline Change in number of household level shocks* $(B)$ & 0.002 & 1.12 \\
\hline Change in number of household level shocks* $(\mathrm{C})$ & $0.095^{\star \star *}$ & 2.23 \\
\hline Change in years of education & $0.051^{* * *}$ & 8.05 \\
\hline Change in household size & $-0.204^{\star \star *}$ & -37.34 \\
\hline Constant & $-0.051^{* * *}$ & -4.37 \\
\hline \multicolumn{3}{|l|}{ Change in payment of bribes } \\
\hline Growth in village welfare programs & $0.041 * \star *$ & 2.70 \\
\hline Bribe Index & $0.227^{\star \star \star}$ & 2.79 \\
\hline Change in prop. of own Jati who paid the bribes & -0.032 & -1.02 \\
\hline Change in prop. of majority Jati who paid the bribes & $0.528^{* * *}$ & 3.97 \\
\hline Size of own Jati & -0.0001 & -0.99 \\
\hline Size of majority Jati & $0.001^{* * *}$ & 5.48 \\
\hline Constant & $0.056^{\star \star *}$ & 3.32 \\
\hline \multicolumn{3}{|l|}{ Change in participation in welfare programs } \\
\hline Change in payments of bribes & $0.014^{\star *}$ & 1.97 \\
\hline Poor (2006)*Paid bribes & $0.212^{* * *}$ & 2.87 \\
\hline Poor (1999)*Paid Bribes & $0.019 * * \star$ & 4.93 \\
\hline Change in payments of bribes*growth in agricultural program & $0.123^{\star \star}$ & 1.92 \\
\hline Change in payments of bribes*arowth in public goods & $0.063^{\star *}$ & 1.98 \\
\hline Change in payments of bribes*growth in untied resources & $0.091^{* *}$ & 1.98 \\
\hline Change in payments of bribes*arowth in welfare programs & 0.030 & 0.91 \\
\hline Growth in village welfare programs & $0.023^{* *}$ & 2.11 \\
\hline Constant & $0.071^{\star * \star}$ & 7.83 \\
\hline Number of observations & \multicolumn{2}{|c|}{5885} \\
\hline Hansen-Sargan overidentification statistic & \multicolumn{2}{|c|}{$3102.524^{\star \star \star}$} \\
\hline
\end{tabular}

NB: ${ }^{*},{ }^{* *},{ }^{* * *}=$ significant at $10 \%, 5 \%, 1 \%$ respectively 
Table 7: Average Odds of Participation and Marginal Odds of Participation in Welfare Programs

\begin{tabular}{|c|c|c|c|c|}
\hline \multirow[b]{2}{*}{$\begin{array}{l}\text { Poor } \\
\text { categories }\end{array}$} & \multicolumn{2}{|c|}{ Not-Paid Bribe } & \multicolumn{2}{|c|}{ Paid bribe } \\
\hline & $\begin{array}{l}\text { Marginal Odds of } \\
\text { Participation (MOP) }\end{array}$ & $\begin{array}{c}\text { AOP } \\
\text { vS. } \\
\text { MOP }\end{array}$ & $\begin{array}{l}\text { Marginal Odds of } \\
\text { Participation (MOP) }\end{array}$ & $\begin{array}{c}\text { AOP } \\
\text { vs. } \\
\text { MOP }\end{array}$ \\
\hline Ultra-Poor & $\begin{array}{c}0.950 * * * \\
(0.061)\end{array}$ & $A O P>M O P$ & $\begin{array}{l}1.67^{\star \star \star} \\
(0.229)\end{array}$ & $\mathrm{AOP}<\mathrm{MOP}$ \\
\hline Poor & $\begin{array}{l}0.608^{\star * *} \\
(0.043)\end{array}$ & $A O P>M O P$ & $\begin{array}{c}1.52^{\star *} \\
(0.073)\end{array}$ & $\mathrm{AOP}<\mathrm{MOP}$ \\
\hline Non-Poor & $\begin{array}{c}0.568 * \star \star \\
(0.026)\end{array}$ & $A O P>M O P$ & $\begin{array}{l}1.01 * \star * \\
(0.137)\end{array}$ & $\mathrm{AOP}<\mathrm{MOP}$ \\
\hline Affluent & $\begin{array}{c}0.669 * * * \\
(0.037)\end{array}$ & $A O P>M O P$ & $\begin{array}{l}0.726 * \star * \\
(0.027)\end{array}$ & $A O P>M O P$ \\
\hline
\end{tabular}

NB: ${ }^{*}, * *{ }^{* \star *}=$ significant at $10 \%, 5 \%, 1 \%$ respectively

Table 8: Rate of growth of Program Participation and Consumption With and Without Bribes

\begin{tabular}{|l|c|c|c|c|c|c|}
\hline & \multirow{2}{*}{$\begin{array}{c}\text { Actual growth } \\
\text { rate of } \\
\text { Categories }\end{array}$} & \multicolumn{2}{|c|}{$\begin{array}{c}\text { Predicted Growth } \\
\text { rate of Program } \\
\text { Program }\end{array}$} & \multicolumn{2}{|c|}{$\begin{array}{c}\text { Actual } \\
\text { Participation (\%) } \\
\text { Participation } \\
\text { (\%) }\end{array}$} & \multicolumn{2}{|c|}{$\begin{array}{c}\text { No } \\
\text { growth rate } \\
\text { (\%) }\end{array}$} & $\begin{array}{c}\text { With } \\
\text { Bribes }\end{array}$ & & \multicolumn{2}{|c|}{$\begin{array}{c}\text { Predicted consumption } \\
\text { growth rate (\%) }\end{array}$} \\
\cline { 7 - 8 } & & & $\begin{array}{c}\text { No Bribes } \\
\text { (with program } \\
\text { participation) }\end{array}$ & $\begin{array}{c}\text { Bribes and } \\
\text { program } \\
\text { participation }\end{array}$ \\
\hline Ultra-poor & 9.08 & 8.18 & 22.44 & 2.01 & 2.06 & 10.65 \\
\hline Poor & 15.57 & 15.87 & 16.62 & 4.66 & 4.15 & 9.82 \\
\hline Non-poor & 12.04 & 9.87 & 8.92 & 6.13 & 6.19 & 6.24 \\
\hline Affluent & & & & 19.83 & 16.7 & 16.33 \\
\hline
\end{tabular}

